\title{
A Rush Hour Ride on the Dwarf Planet: Neotropical Imaginings from a Postpandemic Colony
}

\author{
Christina Yin
}

https://orcid.org/0000-0002-0800-049X

Swinburne University of Technology, Sarawak Campus, Malaysia

\begin{abstract}
In this dystopian flash fiction piece, a colonist on the Dwarf Planet takes the train back to her cubicle after another hard day's work. As she struggles amid the harsh environmental conditions, KAE reflects on why she volunteered to come out to this remote colony in the far reaches of the solar system. It is revealed that the great pandemic of 2020 never ended; the virus mutated and humans fled the Earth to build new worlds on other planets. But glimpses of the world left behind beckon as KAE and her fellow colonists are now being enticed to return to a revived Earth; in particular, to the land of her forebears, Borneo, where orangutans roam in the resurrected rainforest and holiday-makers frolic in the famed underwater world of Sipadan and play on the island's pristine beaches.
\end{abstract}

Keywords: Borneo, COVID-19 pandemic, flash fiction, speculative fiction, dystopian worlds, utopian imaginings, environment, Tropics

eTropic: electronic journal of studies in the tropics publishes new research from arts, humanities, social sciences and allied fields on the variety and interrelatedness of nature, culture, and society in the tropics. Published by James Cook University, a leading research institution on critical issues facing the world's Tropics. Free open access, Scopus Listed, Scimago Q2. Indexed in: Google Scholar, DOAJ, Crossref, Ulrich's, SHERPA/RoMEO, Pandora. ISSN 1448-2940. Creative Commons CC BY 4.0 free to download, save and reproduce. To cite, include: Author(s), Title, eTropic, volume, issue, year, pages and DOI: http://dx.doi.org/10.25120/etropic.20.1.2021.3776 
eTropic 20.1 (2021) Special Issue: Pandemic, Plague, Pestilence and the Tropics

$\mathrm{I}$ t was another day on a crowded platform waiting for the next ride on what she swore was the worst public transportation system in the world. Or maybe in the solar system. Never on time, always crowded, its recycled air smelling of exhausted human toil, the train's carriages swerved and clanked their way through the Dwarf Planet's grey landscape. Through smudged windows, passengers would raise their heavy eyelids to make out the block shapes of human dwellings, their once brightly painted neon rainbow colours blended into slush by the planet's harsh climate.

KÆE shoved her hands in her pockets and gritted her teeth, bouncing back and forth on her heels and toes, impatient. Winter on the dwarf planet was probably the worst season ever; freezing temperatures, howling storms and shrieking winds that pursued every living thing struggling to survive in this bleak corner of the solar system. If it wasn't for the rare minerals and uniquely hardy flora and fauna that were being collected here in the field, and studied in labs back on the moon and other colonised planets, the company wouldn't have invested in transporting humans to this frontier outpost and constructing those blocks of pod cubicles for their habitation.

It was her twentieth winter on the dwarf planet, but KÆE still wasn't used to it. This morning, she had woken to a small window needled with icicles that made their way through the insulation and into her utilitarian sleeping quarters. The company had warned the volunteers about everything except for the bad transportation system and the lousy weather. Now they told everyone to be grateful for the winter, the ice and the rain. These were necessary evils that enabled life on the dwarf planet; the weather was constructed to maintain the cycle of an atmosphere that created the necessary water and air to sustain life.

Hail fell steadily, the wind blowing the icy particles on to the platform and into the faces and bodies of the commuters as they continued to wait. A group of conscripts was huddled in a corner in faded ill-fitting uniforms. It didn't bring KAE any comfort knowing that others were even more uncomfortable than she was.

What had possessed her to sign up for this job on this God-forsaken colony out on the edge of the solar system? Dumb question, but she had to remind herself of the reason she was here every time the winter storms began their cycle. The pandemic of 2020 had never ended; scientists and historians continued to argue about who was responsible for unleashing the Earth's most severe virus outbreak on the human population. Conspiracy theories about American labs deliberately releasing SARSCoV-2, the virus that caused the contagious disease COVID-19 in a city called Wuhan proliferated. It was said that the most powerful country of Earth, back in that time, wanted to destabilise the Chinese government, to decimate the Chinese population; 
eTropic 20.1 (2021) Special Issue: Pandemic, Plague, Pestilence and the Tropics

others claimed virus-avengers tried to obliterate the anti-conservation camps that wanted wildlife like bats to be culled and to open up primary forests for development.

But no matter the cause, the virus could not be defeated. Instead, it had mutated and evolved into the deadliest contagion, felling populations and causing mounting hysteria, enforced isolation and suicides. Money was poured into SpaceX, Blue Origin and Virgin Galactic but it was the humble KittyHawk Glider that made it first, bolting past the finish line of the Space Race. The story was - well, the history books confirmed this - that KEE's ancestors had won a spot in the lucky draw and were among the first colonists on the Moon. Now, many generations later, KÆE was in the far reaches of the solar system. You couldn't deny that the human race was a species of colonists at heart.

When a train finally clattered into the station and its doors reluctantly slid open, KÆE darted in, squeezing herself into a corner of the nearest carriage. She could handle the 15-minute ride crushed next to chained conscripts as she jolted back to her cubicle just a few metres from the Orange line station. Up above, she could see the advertisements flashing to divert passengers from the cramped conditions and foul smells of human bodies after a day's labour.

Holidays on a resuscitated Earth were being advertised. Diving off the Luconia Shoals, Layang Layang and Sipadan; glorious underwater worlds of multi-coloured reefs, sea anemone and nudibranchs waving gently, parrotfish, giant groupers and even whale sharks swimming past. On the surface, holiday-makers frolicked in the shallows; children, shining with a happiness never seen on the dwarf planet, built sand castles on a beach. There was more. Tours deep into the Niah and Mulu Caves, adventurous souls kitted out in paraphernalia led by guides into dark caverns; longhouse bed-sits made from real wood on the edge of an authentic Bornean rainforest near a rehabilitated Batang Ai National Park; longboat rides on the lake created by a dam fed by tributaries of an ancient riverine system. Even the promise of a glimpse of the fabled orangutan and giant Rafflesia flower.

"Looks amazing, doesn't it?" the nearest conscript in green prison garb drawled in her ear.

"I can't believe it's real," KÆE replied, her eyes still on the screen above. "That's where my ancestors came from: Borneo."

"Uh huh, the land of the hornbills, a great island where fabled White Rajahs were supposed to have tamed head hunter warriors? Why do you think they're advertising 
eTropic 20.1 (2021) Special Issue: Pandemic, Plague, Pestilence and the Tropics

these holidays?" the conscript sniggered. "Do you really think Earth is habitable? That tropical rainforests have been replanted and grown again?"

KAE turned to look at the conscript. He was an older man; surprising for the harsh conditions of the dwarf planet. Was he asking a rhetorical question?

"Look at these crowds here on this God-forsaken planet," the conscript babbled on. "I figure they're going to shove us mutineers on the first spaceship back to Earth."

"You're from the Radical Mutineers Cult?" KÆE asked.

"That's what they like to call us," the conscript said with a shrug. "We're just ordinary folk interested in old fashioned twenty-first century meditation and yoga. We couldn't and don't want to hurt anyone. But no one believes us. People are just scared of prespace travel practices." Another shrug. "Does anyone really believe we'll be going back to an Earth that looks like that? I mean, what happened to the virus? And where did all this unpolluted water come from? No more acid rain? How did everything get cleaned up?"

KÆE turned back to the screen. The camera drew the viewer up from the depths of the deep blue ocean all the way through a silent world teeming with living corals, clownfish, leatherback and green turtles, manta rays and creatures she couldn't name. The screen split in two: one side showing the famed underwater French explorer Jacques Cousteau who had called Sipadan off the coast of Borneo the best dive site in the world, "an untouched piece of art"; and the other side depicting the same area resurrected and as pristine today as it had been in 1988 when Cousteau had first explored the island. KÆE watched as the underwater camera rose, following a pod of dolphins that broke the surface of the waters, greeted by blue sky and fluffy white clouds.

As the train squealed to a stop at the next station, jolting the cramped bodies against each other, KÆ squinted at the screen; it was like a little shot of real-life heaven, this Earth that was supposed to have been revived. Could she afford a trip back to a resuscitated Earth? Trek where her ancestors had walked in the rainforest, take a longboat on the river $\mathrm{Ai}$, hear an orangutan call, even see one in the flesh? Could she take a trip to Borneo and dive into those underwater worlds? All around her, passengers scrambled off the swaying carriage while others boarded after the long day's toil on the colonised dwarf planet, but KÆ was oblivious to the rush hour crowd; she was squinting at the sun reflecting off the surface of the South China Sea. 
eTropic 20.1 (2021) Special Issue: Pandemic, Plague, Pestilence and the Tropics

Dr Christina Yin is a former news anchor, journalist, columnist and media executive at an international conservation organisation. Currently Christina is a writer and senior lecturer at Swinburne University of Technology, Sarawak Campus. Her PhD on "Creative Nonfiction: True Stories of People involved in Fifty years of Orang-utan conservation in Sarawak" was the first in Creative Writing at the University of Nottingham Malaysia. Christina's fiction and nonfiction writings have appeared in Anak Sastra, eTropic, New Writing and TEXT, among others. 